\title{
Mannan Antigenemia in the Diagnosis of Invasive
}

\section{Candida Infections}

\author{
Marc H. Weiner and William J. Yount \\ From the Departments of Medicine and Bacteriology and Immunology, \\ University of North Carolina School of Medicine, \\ Chapel Hill, North Carolina 27514
}

A в S T R A C T Because it is often difficult to diagnose invasive Candida infections, a sensitive hemagglutination inhibition assay to detect the surface antigen, mannan, was developed. Mannan antigenemia was detected early in the course of infection in 4 of 14 patients with systemic candidiasis and 2 of 5 patients with invasive gastrointestinal candidiasis. Mannan was not detected in 48 patients with noninvasive Candida or other systemic mycotic infections or in $99 \%$ of 234 patients in other control groups. Mannan antibodies were almost universally present in both candidiasis and control groups. In four patients with systemic candidiasis, an early period of mannan antigenemia was followed by a rapid rise in mannan antibody titer. These findings suggest that antemortem diagnosis would be improved in onethird of cases of invasive Candida infection detected by the hemagglutination inhibition assay. A positive test for serum mannan would be an early and specific signal of invasive disease.

\section{INTRODUCTION}

Systemic candidiasis has been recognized as an important infectious complication in patients with myeloproliferative (1-5) and solid organ tumors $(2,5)$, in immunosuppressed transplant recipients (6), and in patients during the postoperative period $(5,7)$. The antemortem diagnosis of systemic candidiasis is difficult to establish (1-7) because the clinical presentation is usually nonspecific and the microbiologic diagnosis is often difficult to obtain. Deep Candida infection without documented candidemia occurs $28-64 \%$ of the time in re-

A preliminary report of this work has been published (Clin. Res. 23: 31A, 1975), and was presented at the 75th Annual Meeting of The American Society for Microbiology, April 1975.

Dr. Weiner is the recipient of a National Institutes of Health Postdoctoral Research Fellowship AI-01729.

Dr. Weiner's present address is the Department of Medicine, University of Texas Health Science Center, San Antonio, Tex. 78229.

Received for publication 17 November 1975 and in revised form 21 June 1976. ported series (3-7); conversely, transient candidemia without later evidence of systemic disease also occurs (8-9). A microbiologic diagnosis can be delayed while Candida species are being isolated and identified in clinical materials (10).

Several immunologic tests have been evaluated as aids in diagnosis of Candida infections. Skin testing with Candida antigen has been shown to be nondiagnostic for acute infection, because of the high incidence of positive tests in healthy populations (11) and possible anergy in those with overwhelming infections (12). Measurement of serum agglutinins to nonviable Candida cells has in general been unrewarding $(3,13-15)$. The serologic demonstration of precipitins to Candida antigens has improved antemortem diagnosis (4-5); however, mortality remains high. Gaines and Remington (5) reported a $92 \%$ antemortem diagnosis with precipitin techniques, but $42 \%$ mortality secondary to disseminated fungal infection; 9 of 11 patients died before an adequate course of antifungal therapy was completed.

In light of these observations we developed a hemagglutination inhibition assay to detect Candida antigenemia and evaluated the immunoassay retrospectively for its diagnostic usefulness. This paper describes the immunoassay for mannan, a cell wall polysaccharide of several Candida species (16-17), and reports on its application in patients with invasive Candida infections and in control groups.

\section{METHODS}

Patients studied. Sera to be tested were drawn from patients with suspected or proven fungal infections, patients hospitalized for other reasons, and normal blood donors seen at North Carolina Memorial Hospital from June 1972 to January 1975 . Sera were stored frozen at $-20^{\circ} \mathrm{C}$ with sodium azide (final concentration of $0.1 \%$ ).

Critcria for classification of Candida infection. Strict criteria for the diagnosis of systemic candidiasis required histologic evidence in autopsy or biopsy tissue, other than skin or mucosal surfaces, of fungal infection with organisms identified as Candida (18) (eight cases). Autopsy cases with positive postmortem cultures but without histologic demonstration of Candida in tissue were excluded. Of the 
eight cases fulfilling the criteria, four had positive blood cultures for Candida drawn on 2 or more different days with intravenous catheters removed or changed in the interim; and two cases had positive cultures and stains for Candida from material aspirated from abscesses.

Although biopsy material was not available for histopathology, evidence for systemic Candida infection was present in four additional patients. L. F. is described in a case history below. W. Mc. developed peritonitis and pyelonephritis with positive cultures and stains for Candida. M. L. developed Candida endocarditis and hematogenous endophthalmitis with positive blood and bone marrow cultures. M. R., a diabetic with renal failure, had a Candida. renal abscess.

Deep Candida infection could not be excluded in two patients (J. H. and H. C.). They were treated for 10-15 days with antifungal chemotherapy but died from other causes without pathologic evidence at autopsy of Candida infection. They are identified as possible cases of systemic candidiasis.

Invasive gastrointestinal candidiasis (2) was diagnosed histologically in tissue obtained from autopsy (four cases) or surgical pathology (one case).

Superficial Candida infections were diagnosed by clinical appearance with confirmatory culture and stain and(or) biopsy of specimens from the skin, oropharynx, vagina, surgical wound, or urinary bladder. In no case was evidence for deep organ infection present and in no case was systemic therapy required.

Candida colonization was distinguished from superficial or systemic infection by the total absence of clinical or histologic manifestations of infection, although Candida was cultured from nondiagnostic sources listed above. Fungi were isolated from clinical and pathologic specimens and identified using standard techniques (19) in the North Carolina Memorial Hospital Mycology Laboratory.

Cultures and media conditions. Candida albicans group A (strain B311) was kindly donated by Dr. H. F. Hasenclever, National Institutes of Health. Cultures were grown in 2-liter flasks of $1 \%$ neopeptone, $2 \%$ glucose broth (Difco Laboratories, Detroit, Mich.) at $35^{\circ} \mathrm{C}$ for $48 \mathrm{~h}$. The cells were collected by centrifugation at $1,085 \%$, washed twice in normal saline, and frozen at $-20^{\circ} \mathrm{C}$.

Preparation of somatic antigens (" $S$ " antigen). A mixture of somatic and cell wall antigens of Candida " $\mathrm{S}$ " antigen) was prepared by a modification of the procedure of Taschdjian et al. (20). $100-\mathrm{ml}$ aliquots of a $40 \%$ suspension of washed, packed cells in normal saline were added $2: 1$ to $0.5-\mathrm{mm}$ glass chips. The suspension was placed in stainless steel capped tubes immersed in a saltwater ice bath $\left(-2^{\circ} \mathrm{C}\right)$. The cells were disrupted by sonification at maximum gain for 20 min with a Bronson High Intensity Sonifier (Bronson Instruments, Inc., Stamford, Conn.). The slurry was centrifuged at $5,900 \mathrm{~g}$ and the supernates combined. The sediments were washed with normal saline and separated by centrifugation at $5,900 \mathrm{~g}$; all the supernates were pooled and lyophilized. The lyophilized residue was then dissolved in normal saline to one-half the original volume and centrifuged at $5,900 \mathrm{~g}$. The supernate containing " $S$ " antigen was decanted and the protein concentration adjusted to $1.0 \mathrm{mg} / \mathrm{ml}$ with normal saline. Protein concentrations were determined by the Lowry method (21). The mannan concentration of the " $S$ " antigen was determined by the hemagglutination inhibition assay and adjusted with purified mannan to a final concentration of $0.8 \mathrm{mg} / \mathrm{ml}$. "S" antigen was stored in aliquots at $-20^{\circ} \mathrm{C}$.
Preparation of mannan. Mannan was prepared from $C$. albicans group A (B311) by the method of Peat et al. (22) with the tollowing modification substituted for the charcoal purification step. The mannan solution was dialyzed against phosphate-buffered saline (PBS), ${ }^{1} \mathrm{pH} 5.0$, for $48 \mathrm{~h}$ and precipitated in $95 \%$ ethanol $(4: 1, \mathrm{vol} / \mathrm{vol})$. The precipitate was washed twice with $80 \%$ ethanol, dissolved in $35 \mathrm{ml}$ PBS, $\mathrm{pH} 5.0$, and deproteinated by a modification of the method of Sevag (23). Aqueous mannan in PBS, chloroform, and butanol $(20: 5: 1, \mathrm{vol} / \mathrm{vol} / \mathrm{vol})$ was homogenized at $2^{\circ} \mathrm{C}$ for $60 \mathrm{~min}$ in a VirTis 23 homogenizer (VirTis Co. Inc., Gardiner, N. Y.) at maximum speed and layered by centrifugation at $12,000 \mathrm{~g}$ for $15 \mathrm{~min}$. The mannan solution after 15 extractions was reprecipitated in $95 \%$ ethanol (4:1, vol/vol), washed twice with $80 \%$ ethanol, dissolved in $30 \mathrm{ml} \mathrm{PBS} \mathrm{pH} 7.0$, centrifuged $4 \mathrm{~h}$ at $140,000 \mathrm{~g}$, precipitated in $95 \%$ ethanol $(4: 1, \mathrm{vol} / \mathrm{vol})$, washed twice with absolute ethanol, and vacuum dried. The final protein concentration was $3 \%$ of the total dry weight. Concentrations of the highly purified preparations of mannan were determined by dry weight.

Mannans from C. albicans group B (strain 526), C. stcllatoidca (strain 2,864) and $C$. tropicalis (strain 48) were a gift from Dr. H. F. Hasenclever.

Mannan analysis. Quantitative precipitation of mannan was performed by the method of Kabat and Mayer (24). Sucrose density gradient $(10-40 \% \mathrm{wt} / \mathrm{vol})$ centrifugation was used to characterize mannan and antigen-antibody complexes (25). Mannan, mannan-antibody complexes, patient sera in antigen excess, and sera in transition zones were treated by the method of $\mathrm{Yu}-\mathrm{Teh} \mathrm{Li}$ and Su-Chen $\mathrm{Li}$ (26) with $\alpha$-mannosidase (Sigma Chemical Co., St. Louis, Mo.) prepared from jack bean meal.

Antisera. New Zealand albino rabbits weighing $4-5 \mathrm{~kg}$ were immunized biweekly with either "S" antigen emulsified in Freund's complete adjuvant (Difco Laboratories) or whole Candida cells. Animals were bled on the 9th wk, and every 2 wk thereafter. In addition, serum from patient L. F with a high titer antimannan antibody was used as a specific agglutinator in the hemagglutination inhibition assay. Antiserum to $\mathrm{Clq}$ was prepared by the method of Agnello et al. (27).

Immunoprecipitin techniques. Single radial immunodiffusion was performed by the method of Mancini et al. (28). Immunoelectrophoresis was performed by the method of Scheidegger (29). Double diffusion precipitin technique, used to detect "S" antigen, was performed by the method of Ouchterlony (30). All gel precipitin systems employed $2 \%$ agar (Noble, Difco Laboratories) in veronal buffer, 0.05 ionic strength, $\mathrm{pH} 8.4$, except single radial immunodiffusion where $1 \%$ agarose (Marine Colloids Inc., Rockland, Maine) was employed. Immune complexes were detected by the technique of $\mathrm{C} 1 \mathrm{q}$ precipitin testing in EDTA agarose using purified $\mathrm{Clq}$ as described by Agnello et al. (27).

Passiz' hemagglutination (PH) assay for antimannan antibody. The passive hemagglutination technique was based on the method of Leon and Young (31) for coating glycoproteins and polysaccharides to sensitized sheep erythrocytes. Optimal sensitization, as determined by two-dimensional titrations, was achieved with $50 \mu \mathrm{g} / \mathrm{ml}$ concanavalin A (Sigma Chemical Co.) and $30 \mu \mathrm{g} / \mathrm{ml} \mathrm{C}$. albicans group A (B311) mannan. All test sera were heat inactivated by in-

1 Abbreviations used in this paper: HI, hemagglutination inhibition; PBS, phosphate-buffered saline; $\mathrm{PH}$, passive hemagglutination. 
cubation at $56^{\circ} \mathrm{C}$ for $30 \mathrm{~min}$. Serial dilutions of test sera were prepared in buffer $\left(0.9 \% \mathrm{NaCl}, 0.01 \mathrm{M} \mathrm{NaH}_{2} \mathrm{PO}_{4}\right)$, $\mathrm{pH} 7.3$, with $2 \%$ heat inactivated fetal calf serum. The passive hemagglutination assay was adopted to a microtiter plate system.

Mannan antibody was detected by adding $50 \mu \mathrm{l}$ of $0.15 \%$ suspension of sensitized erythrocytes to $50 \mu \mathrm{l}$ of buffer and $50 \mu 1$ of test serum. The cells were allowed to settle without centrifugation. The highest dilution of serum that caused $1^{+}$agglutination of sensitized erythrocytes (a carpet of cells with a ring at the edge) was regarded as the end point. Test sera were absorbed with washed sheep erythrocytes $(4: 1, \mathrm{vol} / \mathrm{vol})$ for $30 \mathrm{~min}$ at room temperature and 60 min at $4^{\circ} \mathrm{C}$ and tested with uncoated cells to assure absorption of heterophile antibody. As a control for specificity, $C$. albicans group A mannan was added to sera exhibiting agglutination ( $50 \mu 1$ of mannan $2 \mathrm{mg} / \mathrm{ml}$ ) to insure that hemagglutination was inhibited.

Hemagglutination inhibition $(H I)$ assay for mannan. An $\mathrm{HI}$ assay was developed using immune human antiserum from patient L. F. diluted twofold below maximum agglutination titer. If a test serum was without antimannan anti- body, the HI assay could be used to detect mannan antigen. $50 \mu \mathrm{l}$ of the test sera was incubated with $50 \mu \mathrm{l}$ of the diluted L. F. antibody and $50 \mu 1$ of $0.15 \%$ suspension of sensitized sheep erythrocytes. The inhibition of hemagglutination indicated mannan antigenemia. C. albicans group A mannan either in buffer or in human serum specifically inhibited the system and was employed as a positive control.

\section{RESULTS}

Clinical findings in patients with systemic candidiasis. The clinical and pathologic data on the 14 cases of systemic candidiasis are summarized in Table I. There were nine males and five females ranging in age from 2 to $76 \mathrm{yr}$ with a mean age of $52 \mathrm{yr}$. A variety of predisposing conditions was present. One patient was leukopenic and six of eight skin-tested patients were nonreactive to intradermal intermediate strength purified protein derivative, Candida, and mumps antigens. 8 of 14 cases had documented bacteremia and all 14 received

TABLE I

Summary of Clinical, Microbiologic, and Pathologic Data in Patients wtih Systemic Candidiasis

\begin{tabular}{|c|c|c|c|c|c|c|c|c|c|c|c|c|c|c|c|c|c|}
\hline \multirow[b]{2}{*}{ Patients } & \multirow[b]{2}{*}{$\begin{array}{l}\text { Age, } \\
\text { sex }\end{array}$} & \multirow[b]{2}{*}{$\begin{array}{l}\text { Underlying disease } \\
\text { or conditions }\end{array}$} & \multirow[b]{2}{*}{$\begin{array}{l}\text { Skin } \\
\text { tests* }\end{array}$} & \multirow[b]{2}{*}{$\begin{array}{l}\text { Predis- } \\
\text { posing } \\
\text { therapy } \ddagger\end{array}$} & \multirow[b]{2}{*}{$\begin{array}{l}\text { Candida } \\
\text { species }\end{array}$} & \multicolumn{7}{|c|}{ Candida isolations } & \multicolumn{3}{|c|}{$\begin{array}{c}\text { Antifungal } \\
\text { therapy }\end{array}$} & \multirow[b]{2}{*}{$\begin{array}{l}\text { Out- } \\
\text { come }\end{array}$} & \multirow[b]{2}{*}{$\begin{array}{l}\text { Organs found } \\
\text { infected at } \\
\text { biopsy or autopsy }\end{array}$} \\
\hline & & & & & & है & 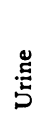 & $\stackrel{D}{\tilde{Z}}$ & 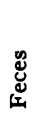 & $\frac{\overrightarrow{0}}{m}$ & 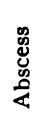 & 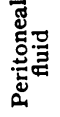 & AmB & $5 \mathrm{FC}$ & $\begin{array}{c}I \\
\text { and } \\
D\end{array}$ & & \\
\hline L. F. & $55, F$ & Renal failure & $\mathbf{R}$. & A & C. tropicalis & + & + & & & & & + & + & + & & Lived & \\
\hline E. St. & 59. M & $\begin{array}{l}\text { Diabetes mellitus, } \\
\text { abdominal operation, } \\
\text { bacteremic sepsis }\end{array}$ & & $\mathbf{A}$ & C. tropicalis & + & + & + & & & + & & + & & & Died & $\begin{array}{l}\text { Heart, lung, trachea, } \\
\text { kidney }\end{array}$ \\
\hline W. Mc. & 76. $\mathrm{M}$ & $\begin{array}{l}\text { Renal failure, } \\
\text { bacteremic sepsis }\end{array}$ & N. R. & $\mathbf{A}$ & C. albicans & + & + & & & & & + & + & & & Died & No autopsy \\
\hline A. V. & $67, \mathrm{M}$ & $\begin{array}{l}\text { Rocky mountain } \\
\text { spotted fever, } \\
\text { bacteremic sepsis }\end{array}$ & & A, S, IV & $\begin{array}{l}\text { C. tropicalis } \\
\text { C. stellatoidea }\end{array}$ & + & + & & & + & & + & & & & Died & $\begin{array}{l}\text { Heart, lung, kidney, } \\
\text { brain, bowel, liver } \\
\text { adrenal }\end{array}$ \\
\hline M. R. & $46, F$ & $\begin{array}{l}\text { Diabetes mellitus, } \\
\text { bacteremic sepsis }\end{array}$ & & A, S & C. parapsilosis & + & + & & & & + & & + & & + & Lived & $\|$ \\
\hline E. Sn. & $50, \mathrm{M}$ & Cachexia & N. R. & A, IV & C. albicans & + & & + & & + & + & & + & & + & Lived & Vein \\
\hline H. V. & $63, F$ & $\begin{array}{l}\text { Macroglobulinemia, } \\
\text { bacteremic sepsis }\end{array}$ & N. R. & A & C. tropicalis & + & + & & & & & & & & & Died & $\begin{array}{l}\text { Heart blood, lung. } \\
\text { kidney }\end{array}$ \\
\hline J. B. & $65, \mathrm{M}$ & $\begin{array}{l}\text { Renal failure, } \\
\text { nephrolithiasis, } \\
\text { abdominal operation }\end{array}$ & & $\mathbf{A}$ & C. tropicalis & & + & + & + & & + & & + & & + & Died & Kidney \\
\hline R. L. & $54, \mathrm{M}$ & Abdominal operation & $\mathbf{R}$. & A, S, IV & C. albicans & + & + & + & & + & & & & & & Died & $\begin{array}{l}\text { Heart, lung, kidney, } \\
\text { brain }\end{array}$ \\
\hline B. C. & $56, \mathrm{~F}$ & $\begin{array}{l}\text { Alcoholic hepatitis, } \\
\text { bacteremic sepsis }\end{array}$ & N. R. & $\mathbf{A}$ & C. albicans & + & + & & + & & & & + & & & Died & Heart blood, lung \\
\hline M. L. & $34, F$ & Marfan's syndrome & N. R. & A, IV & C. parapsilosis & & + & & & + & & & + & & & Lived & \\
\hline D. N. & $2, \mathrm{M}$ & $\begin{array}{l}\text { Stevens-Johnson } \\
\text { bacteremic sepsis }\end{array}$ & & IV, A, S & C. albicans & + & + & & & + & & & & + & & Died & Kidney, lung, skin \\
\hline J. H. I & 39. $\mathrm{M}$ & $\begin{array}{l}\text { Renal transplant, } \\
\text { bacteremic sepsis }\end{array}$ & N. R. & $\mathrm{A}, \mathrm{S}, \mathrm{C}$ & C. albicans & $+* *$ & + & & & & & & + & & & Died & None \\
\hline H. C. I & $61, \mathrm{M}$ & Metastatic cancer & & $\mathbf{A}, \mathbf{S}$ & C. albicans & & + & & & & + & & & + & & Died & None \\
\hline
\end{tabular}

* $R$., reactive; N. R., nonreactive, to battery of purified protein derivative-I, monilia (HS), and mumps.

$\ddagger \mathrm{A}$, antibiotics; S, corticosteroids; IV, intravenous hyperalimentation; $\mathrm{C}$, cytotoxic chemotherapy.

\$ AmB, amphoteracin B; 5FC, 5-fluorocytosine; I and D, incision and drainage.

|l Died 1 mo later of renal failure without evidence of Candida infection at autopsy.

I Possible cases of systemic candidiasis (see text).

** Positive multiple transtracheal and bronchoscopy aspirates. 


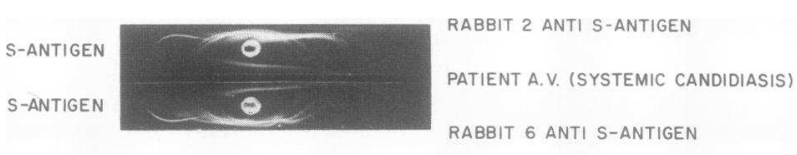

PURIFIED

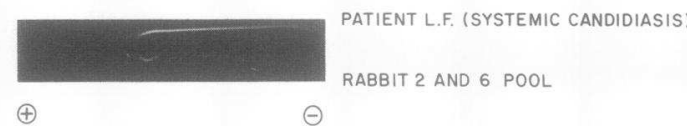

FIGURE 1 Immunoelectrophoresis of sonicate of whole Candida albicans (" $\mathrm{S}$ " antigen) in upper and middle wells. The anode is on the left. Rabbits immunized with "S" antigen exhibit specificity for 15 Candida antigens. Sera from patients A. V. and L. F. with systemic candidiasis recognize a cathodally migrating antigen which was identified as cell wall mannan.

courses of broad spectrum antibiotics. Additional predisposing features included treatment with corticosteroids in five cases, and cytotoxic chemotherapy in one case.

In 11 cases $(79 \%)$, the diagnosis was clinically suspected and antifungal chemotherapy and(or) drainage initiated. However, systemic fungal disease was the primary or major contributing cause of death in eight cases. Of those who died, three patients received no systemic antifungal chemotherapy and four patients received inadequate courses. In the latter group, specific antifungal chemotherapy was initiated preterminally. Disseminated Candida infection was documented in 5 of 10 cases coming to autopsy.

Clinical findings in patients with superficial Candida infections or zuith colonization with Candida. The ages of the 38 subjects in these control groups ranged from
18 to $84 \mathrm{yr}$ with a mean age of $52 \mathrm{yr}$. Associated or underlying conditions included myeloproliferative or solid organ tumors (11 cases), postoperative state ( 7 cases), systemic collagen vascular disease ( 7 cases), diabetes mellitus ( 5 cases), severe burn ( 2 cases), and bacterial sepsis (18 cases). 14 patients were anergic and 6 leukopenic. Additional predisposing features included broad spectrum antibiotic therapy in 31 cases, cytotoxic chemotherapy or irradiation in 12 cases, corticosteroid therapy in 6 cases, and intravenous hyperalimentation in 6 cases.

Precipitins to "S" antigen. In rabbits immunized with "S" antigen, specificity for at least 15 separate antigens from $C$. albicans was identified in individual bleedings from six different animals (Fig. 1). In contrast, the initial humoral immune response was directed toward the cell-surface polysaccharide mannan in sera from five patients with systemic candidiasis. On immunoelectrophoresis, $C$. albicans group A mannan was found to migrate cathodally to yield a characteristic precipitin arc which was the major precipitin arc developed by human sera containing antibody to crude "S" antigen. Precipitins to "S" antigen were detected in 9 of 14 patients with systemic candidiasis (Table II) at a maximum titer of $1: 8$. Precipitins to " $\mathrm{S}$ " antigen characteristically developed relatively late in the course of infection. For example, in patient L. F., precipitins did not develop until 10 days after the first demonstration of serum mannan, 7 days after the clinical recognition of systemic disease, and 4 days after clinical improvement with antifungal chemotherapy. In patient E. St., serum precipitins were first detected only 1 day before death caused

TABLE II

Antibody to " $S$ " Antigen and Mannan Antigen and Antibody in Systemic Candidiasis

\begin{tabular}{|c|c|c|c|c|c|c|c|}
\hline \multirow[b]{2}{*}{ Patient } & \multirow[b]{2}{*}{$\begin{array}{l}\text { No. of } \\
\text { sera }\end{array}$} & \multirow{2}{*}{$\begin{array}{c}\begin{array}{c}\text { Precipitin } \\
\text { to "S" } \\
\text { antigen }\end{array} \\
\begin{array}{c}\text { Maximum } \\
1 / \text { titer }\end{array}\end{array}$} & \multicolumn{2}{|c|}{ Serum mannan-HI } & \multicolumn{3}{|c|}{ Antimannan antibody-PH } \\
\hline & & & $\begin{array}{l}\text { sera } \\
\text { positive }\end{array}$ & $\begin{array}{c}\text { Maximum } \\
1 / \text { titer }\end{array}$ & $\underset{1 / \text { titer }}{\text { Minimum }}$ & $\begin{array}{c}\text { Maximum } \\
1 / \text { titer }\end{array}$ & $\begin{array}{c}\Delta \text { Antibody } \\
\text { titer } \log _{2}\end{array}$ \\
\hline 1. L. F. & 25 & 8 & 7 & 32 & 0 & 66,000 & 17 \\
\hline 2. E. St. & 17 & 1 & 6 & 8 & 0 & 1,000 & 11 \\
\hline 3. W. Mc. & 10 & 0 & 2 & 8 & 0 & 256 & 8 \\
\hline 4. A. V. & 9 & 1 & 1 & 16 & 0 & 4,000 & 13 \\
\hline 5. M. R. & 31 & 2 & 0 & 0 & 1 & 1,000 & 11 \\
\hline 6. E. Sn. & 12 & 1 & 0 & 0 & 1 & 2,000 & 12 \\
\hline 7. H. V. & 6 & 0 & 0 & 0 & 32 & 256 & 3 \\
\hline 8. J. B. & 8 & 1 & 0 & 0 & 1,000 & 2,000 & 1 \\
\hline 9. R. L. & 7 & 1 & 0 & 0 & 32 & 128 & 2 \\
\hline 10. B. C. & 8 & 0 & 0 & 0 & 8 & 32 & 2 \\
\hline 11. M. L. & 1 & 1 & 0 & 0 & - & 8 & - \\
\hline 12. D. N. & 1 & 0 & 0 & 0 & - & 4 & - \\
\hline 13. J. H. & 7 & 0 & 0 & 0 & 8 & 64 & 3 \\
\hline 14. H. C. & 4 & 1 & 0 & 0 & 32 & 64 & 1 \\
\hline
\end{tabular}


TABLE III

Mannan Antigen, Antibody, and Antibody to " $S$ " Antigen in Candidiasis and Control Groups

\begin{tabular}{|c|c|c|c|c|c|c|c|}
\hline \multirow[b]{2}{*}{ Patient studied } & \multirow[b]{2}{*}{$\begin{array}{l}\text { No. of } \\
\text { patients }\end{array}$} & \multirow[b]{2}{*}{$\begin{array}{l}\text { No. of } \\
\text { sera }\end{array}$} & \multicolumn{2}{|c|}{ Antigen positive-HI } & \multicolumn{2}{|c|}{ Mannan antibody positive-PH } & \multirow{2}{*}{$\begin{array}{c}\text { No. of patients } \\
\text { with positive } \\
\text { precipitins } \\
\text { to " } \mathrm{S} \text { " } \\
\text { antigen }\end{array}$} \\
\hline & & & $\begin{array}{l}\text { No. of } \\
\text { patients }\end{array}$ & $\begin{array}{l}\text { Mean maximum } \\
\text { titer } \pm \mathrm{SD}^{*}\end{array}$ & $\begin{array}{l}\text { No. of } \\
\text { patients }\end{array}$ & $\begin{array}{c}\text { Mean maximum } \\
\text { titer } \pm \mathrm{SD}^{*}\end{array}$ & \\
\hline & & & $(\%)$ & & $(\%)$ & & $(\%)$ \\
\hline Systemic candidiasis & 14 & 146 & $4(29)$ & $3.75 \pm 0.96$ & $14(100)$ & $8.21 \pm 3.77$ & $9(64)$ \\
\hline $\begin{array}{l}\text { Gastrointestinal } \\
\text { candidiasis }\end{array}$ & 5 & 17 & $2(40)$ & 5 & $4(80)$ & $5.75 \pm 2.50$ & $1(20)$ \\
\hline $\begin{array}{l}\text { Candidemia associated } \\
\text { with intravenous } \\
\text { catheters }\end{array}$ & 4 & 41 & $0(0)$ & 0 & $4(100)$ & $10.00 \pm 1.83$ & $3(75)$ \\
\hline Superficial candidiasis & 20 & 79 & $0(0)$ & 0 & $20(100)$ & $6.52 \pm 3.00$ & $4(20)$ \\
\hline $\begin{array}{l}\text { Colonization with } \\
\quad \text { Candida }\end{array}$ & 18 & 44 & $0(0)$ & 0 & $18(100)$ & $5.78 \pm 2.47$ & $2(11)$ \\
\hline $\begin{array}{l}\text { Other mycotic } \\
\text { infections } \downarrow\end{array}$ & 10 & 31 & $0(0)$ & 0 & $31(100)$ & $6.00 \pm 3.77$ & \\
\hline $\begin{array}{l}\text { Miscellaneous hospital } \\
\text { patients } \\
\text { Normal blood donors } \\
\text { Normal children }\end{array}$ & $\begin{array}{r}144 \\
76 \\
14\end{array}$ & $\begin{array}{r}147 \\
76 \\
14\end{array}$ & $\begin{array}{l}2(1.3) \\
1(1.3) \\
0(0)\end{array}$ & $\begin{array}{l}2 \\
2 \\
0\end{array}$ & $\begin{array}{c}143(99.3) \\
75(98.7) \\
14(100)\end{array}$ & $\begin{array}{l}4.92 \pm 2.94 \\
5.54 \pm 1.57 \\
3.93 \pm 2.56\end{array}$ & \\
\hline
\end{tabular}

Numbers in parentheses refer to the percentages in their respective columns.

* Titer expressed as the $\log _{2}$.

$\ddagger$ Includes two cases of systemic aspergillosis, three of blastomycosis, three of cryptococcosis, one of acute histoplasmosis, and one of mucormycosis.

by disseminated Candida infection. Precipitins to "S" antigen could be detected in control populations without systemic Candida infection, in 4 of 20 patients with superficial Candida infections, and in 2 of 18 patients colonized with Candida (Table III).

Antimannan antibody detected by passive hemagglutination. Passive hemagglutination of sheep cells coated with mannan proved to be a sensitive test for the detection of antimannan antibody. Mannan antibodes were detected by passive hemagglutination earlier in the clinical course than by precipitins, and were detected in all $14 \mathrm{pa}-$ tients with systemic candidiasis and in 4 of 5 patients with invasive gastrointestinal candidiasis (Table III). They were not detected in 28 sera from six patients with invasive Candida infections who exhibited mannan antigenemia. At least a 4-fold rise in antibody titer occurred in 10 of 12 patients with systemic candidiasis who were followed serially; a 264-66,000-fold increase in titer was observed in 5 patients. Among the control groups, mannan antibody was almost universally detected (Table III). The mean maximum titers of the patients with systemic candidiasis and with candidemia associated with intravenous catheters were higher than other groups studied, although overlap in antibody titer in individuals of different groups occurred. Maximum increases of 264-fold in antibody titer were documented in serial sera from patients with transient candidemia as- sociated with infected intravenous catheters and patients with superficial Candida infections.

Mannan characterized by the $H I$ assay. C. albicans group A mannan run on a linear $10-40 \%$ sucrose density gradient was detected by the $\mathrm{HI}$ assay in a broad spectrum of molecular weights from 150,000 to 900,000 . By the technique of single radial immunodiffusion, with rabbit antibody or antibody from $L$. F., a minimum concentration of $150 \mu \mathrm{g} / \mathrm{ml}$ of mannan was detectable. However with the HI assay, $0.3 \mu \mathrm{g} / \mathrm{ml}$ of $C$. albicans group A mannan could routinely be detected. Mannans prepared from $C$. albicans group B, C. tropicalis, and $C$. stellatoidea were cross-reactive in the HI system, whereas dextran, sucrose, $\mathbf{D}(+)$-mannose, or mannan purified from Saccharomyces cerevisiae were not.

Evidence of the specificity of the HI assay for mannan was obtained by treatment of sera from patients with systemic candidiasis with $\alpha$-mannosidase, a glycosidase which can hydrolyze mannose from natural $\alpha$-mannoside carbohydrates and glycoproteins. Eight sera from four patients were selected because they demonstrated mannan antigenemia or because they were in transition zones from an antigenemic phase to the appearance of mannan antibody. Sera treated with $\alpha$-mannosidase demonstrated loss of mannan antigen and in some sera release of free antibody. The mean increase in antibody titer expressed $\log _{2}$ was $2.29 \pm 1.30$ (SD) compared to con- 


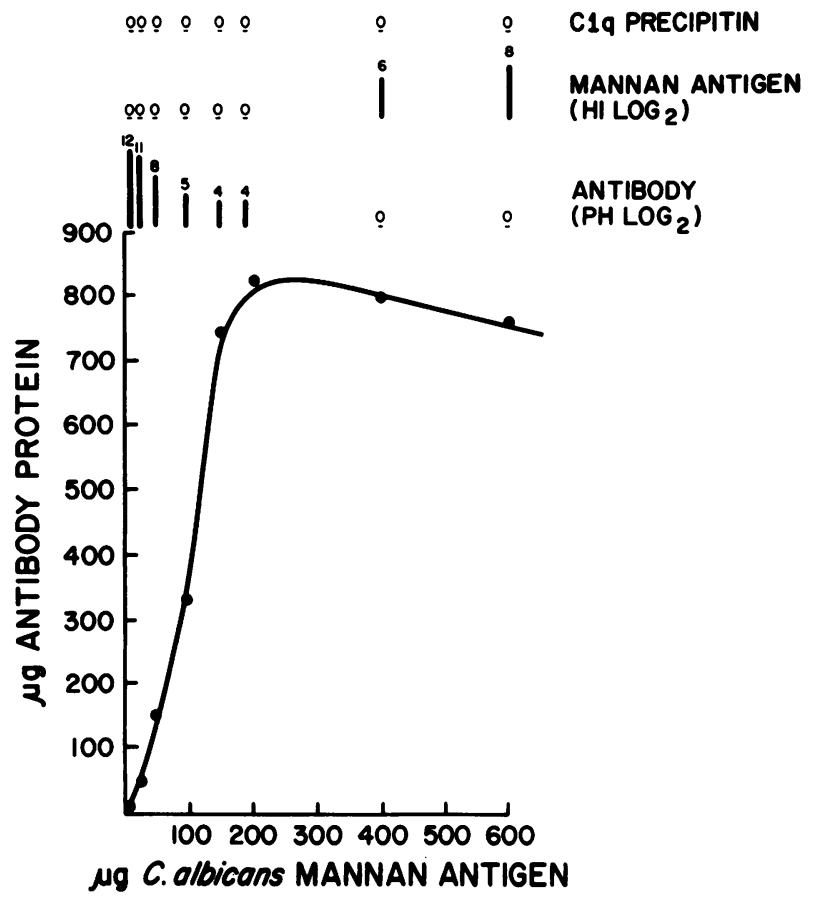

FIGURE 2 Quantitative precipitin curve of serum from patient L. F. vs. C. albicans group A mannan. Mannan antibody and antigen could be readily detected in supernates in zones of antibody and antigen excess by passive hemagglutination and hemagglutination inhibition assays respectively. Soluble immune complexes could not be detected by the Clq precipitin assay in the zone of antigen excess.

trols. Sera from two normal subjects with low antimannan antibody titer was unaffected by $\alpha$-mannosidase treatment. Recovery of mannan antibody from purified immune precipitates was enhanced by $\alpha$-mannosidase treatment. Finally, $\alpha$-mannosidase by itself did not cause nonspecific agglutination of mannan sensitized erythrocyes.

Serum from patient L. F., which contained a high titer antimannan antibody and was used extensively in the HI assay, was initially studied by quantitative precipitin techniques using $C$. albicans group A mannan (Fig. 2). At equivalence $200 \mu \mathrm{g}$ mannan precipitated 820 $\mu \mathrm{g}$ antimannan antibody per $0.5 \mathrm{ml}$ heat inactivated serum. A linear relationship of antibody vs. concentration of antigen was noted in immune precipitates in the zone of antibody excess. Antibody and antigen could be readily detected in supernates in the zones of antibody and antigen excesses by $\mathrm{PH}$ and HI respectively. Soluble complexes could not be detected by the $\mathrm{C} 1 \mathrm{q}$ precipitin assay in the zone of antigen excess.

Mannan antigenemia in invasive candidiasis. A total of 305 patients were studied (Tables II-III). With the HI assay, mannan antigenemia was documented early in the course of 4 of 14 patients with systemic candidiasis (Table II). Of these 14 cases, 8 were proved to have systemic infections by histologic criteria and in 2 of these 8 patients, antigenemia was detected. Four patients were diagnosed as having systemic candidiasis from positive antemortem cultures (histopathology unavailable). Antigenemia was detected in two of these cases. In the two patients with possible systemic candidiasis, antigenemia was not detected.

Fungemia was detected in only one of the four patients with antigenemia, although a minimum of six blood cultures were drawn in each case. In those patients in whom antifungal chemotherapy was started, blood cultures were drawn before treatment. Mannan was present in three patients up to 10 days before the development of precipitins to Candida cytoplasmic or cell wall antigens. After intervals of 1-6 days, antigenemia cleared, and mannan antibody was detected in rising titers. All 14 patients with systemic candidiasis developed antimannan antibody detected by passive hemagglutination. The 10 patients who were antigen negative were positive at the outset for mannan antibody.

Mannan was also detected in sera from two of five patients with invasive gastrointestinal candidiasis ( $\mathrm{Ta}$ ble III). In these two cases, more extensive gastrointestinal involvement was found at autopsy: multiple extensive ulcerations of stomach, and small and large intestines with pseudohyphae extending into the muscular layer were found in one case; and ulcerative esophagitis in the second.

Mannan was not detected, however, in sera from 20 patients with superficial Candida infections, 18 patients colonized with Candida, and 10 patients with other systemic mycotic infections. Among other control patients, mannan-like activity was detected in low titer in single specimens from 2 of 144 miscellaneous hospital patients and in 1 of 76 random blood donors, and in none of 14 normal children. Follow-up serologic examination was possible in one of the two hospital patients who were without fungal disease but who had a positive HI assay. The patient was found to have multiple myeloma with an IgA, $\kappa \mathrm{M}$ component. However, repeat tests for mannan antigenemia on days after the initial positive test were negative. Three sequential studies detected only antimannan antibody at a titer of $1: 32$.

The data was statistically analyzed with Fisher's exact test. Only the first serum specimen from a patient or control was considered to allow comparison among different groups. The association of mannan antigenemia with systemic candidiasis $(P<0.05)$ and with invasive gastrointestinal candidiasis $(P<0.005)$ was significant when compared to a group of normal blood donors and patients hospitalized for other reasons. The association of mannan antigenemia with invasive Candida infections (systemic candidiasis and invasive gastrointestinal candidiasis) was significant $(P<0.05)$ when compared to 
the group of patients with superficial Candida infections, colonization with Candida and other systemic fungal infections.

Illustrative case. Patient L. F. (Table IV). A 55-yrold female was transferred from another hospital because of acute renal failure, severe metabolic acidosis, and depressed sensorium. On hospital day 2 at the end of a 36-h peritoneal dialysis, the peritoneal fluid return was yellow and cloudy. Physical examination demonstrated abdominal signs of peritonitis. Gram stain and $\mathrm{KOH}$ preparations demonstrated yeast forms from urine, sputum and peritoneal fluid obtained both from the peritoneal dialysis catheter and by separate paracentesis. The patient was treated with $1.5 \mathrm{~g}$ of 5-fluorocytosine that evening. On the $3 \mathrm{rd}$ hospital day, $5 \mathrm{mg}$ of amphotericin B was infused intraperitoneally, followed by $5 \mathrm{mg}$ intravenously. Nystatin was given orally. Over the next 6 days, $120 \mathrm{mg}$ of amphotericin B was given parenterally. Cultures were later reported to have grown $C$. tropicalis from three peritoneal fluid specimens, from a tracheal aspirate, and from urine. Eight blood cultures taken over the first 3 days were sterile. The patient clinically improved with return of renal function and resolution of peritonitis. She was discharged on the 20th hospital day. Follow-up examinations to the 20 th month have failed to demonstrate recurrent fungal infection.

Prospectively, serum precipitins to "S" antigen were not demonstrated until the 10th hospital day. Retrospective testing documented mannan antigenemia in seven different sera over the first $\mathbf{5}$ hospital days. After antifungal chemotherapy was started, mannan disappeared from the serum. Antimannan antibody detected by passive hemagglutination appeared on the 6th hospital day and by the 14th hospital day reached a titer of $1: 66,000$. Serum precipitins were not detected until 10 days after the first demonstration of serum mannan, 7 days after the patient was first treated with antifungal chemotherapy, and 4 days after the patient had clinically improved.

\section{DISCUSSION}

The difficulties of diagnosis and treatment of systemic Candida infection prompted this investigation (1-10). What we sought was a serologic test that did not depend upon host immune response for diagnosis, but on the early detection of Candida antigen in serum which might correlate with disease activity. Surface carbohydrate antigens to a variety of organisms have proved useful in this regard. Pneumococcal (32), meningococcal (33), and cryptococcal (34) polysaccharides had been detected in serum and other body fluids in infections before isolation of the microorganism. Our prelinninary studies demonstrated in patients with systemic candidiasis a humoral response directed predominantly toward the Candida surface polysaccharide, mannan. When relatively insensitive immunoprecipitin techniques failed
TABLE IV

Patient L. F. Candida Peritonitis

\begin{tabular}{rccr}
\hline $\begin{array}{c}\text { Hospital } \\
\text { day }\end{array}$ & $\begin{array}{c}\text { Precipitin } \\
\text { to "S" } \\
\text { antigen }\end{array}$ & $\begin{array}{c}\text { Serum } \\
\text { mannan-HI }\end{array}$ & $\begin{array}{c}\text { Mannan } \\
\text { antibody-PH }\end{array}$ \\
\hline & & $1 /$ titer & \\
0 & 0 & 32 & 0 \\
1 & 0 & 16 & 0 \\
2 & 0 & 16 & 0 \\
3 & 0,0 & 16,8 & 0,0 \\
4 & 0 & 4 & 0 \\
5 & 0 & 8 & 0 \\
6 & 0 & 0 & 4 \\
8 & 0 & 0 & 256 \\
9 & 0 & 0 & 2,000 \\
10 & 1 & 0 & 2,000 \\
11 & 2 & 0 & 8,000 \\
12 & & 0 & 8,000 \\
14 & 8 & 0 & 66,000 \\
15 & & 0 & 33,000 \\
18 & & 0 & 66,000 \\
25 & & 0 & 2,000 \\
46 & & 0 & 2,000 \\
60 & & 0 & 1,000 \\
270 & 0 & 0 & 128 \\
\hline
\end{tabular}

to detect mannan antigenemia, we developed a sensitive hemagglutination inhibition assay for mannan.

Mannan is a major cell-surface antigen of several Candida species $(17,35)$. There are two recognized serologic groups of $C$. albicans mannan, group $\mathrm{A}$ and group B (17). Group A mannan is a highly branched homopolysaccharide with short side-chains of $\alpha-(1 \rightarrow 2)$ linked mannose residues joined together by $\alpha-(1 \rightarrow 6)$ linkages (16) and is antigenically very similar to mannan from $C$. tropicalis. By the technique of inhibition of agglutination of whole yeast cells, prior studies have demonstrated good cross reactivity between mannans extracted from $C$. albicans group A, C. albicans group B, C. tropicalis, C. stellatoidea, and $S$. cerevisiae (17). $2 \mu \mathrm{g}$ of homologous purified mannan significantly inhibited the agglutination of whole cells, despite the use of antisera prepared with whole cells as immunogen. In light of these observations, we used a $C$. albicans group A mannan and a human antibody to $C$. tropicalis to develop a HI assay which would detect a broad range of mannans from Candida species. Thus, with the HI assay cross-reactivity was demonstrated with mannans prepared from C. albicans group A, C. albicans group B, $C$. tropicalis, and C. stellatoidea; and in six cases of invasive Candida infection in which mannan antigenemia was detected, the pathogen in three was $C$. albicans and in three C. tropicalis.

To test the HI assay for specificity for mannan, sera obtained from patients at the time of invasive Candida 
infections were treated with an $\alpha$-mannosidase which hydrolyzes mannose from natural $\alpha$-mannoside carbohydrates and glycoproteins. Treatment of these sera resulted in disappearance of mannan from serum, and either recovery or increased activity of mannan antibody.

The HI assay was evaluated by correlating mannan antigenemia with clinical events during the course of systemic infection. In this way, early in the course of disease, before the appearance of precipitins to " $\mathrm{S}$ " antigen, mannan antigenemia was documented in 4 of 14 patients with systemic candidiasis and 2 of 5 patients with invasive gastrointestinal candidiasis. Notably, in three patients with mannan antigenemia and systemic Candida infections, fungemia could not be documented in blood cultures. After 1-6 days, antigenemia cleared with or without antifungal chemotherapy, and mannan antibody appeared in rising titer. In two patients with invasive gastrointestinal candidiasis, the detection of mannan antigenemia suggested absorption of mannan from ulcerated visceral lesions. The detection of antibodies to "S" antigen late in the clinical course generally correlated with high titer mannan antibody detected by passive hemagglutination. The presence of mannan antigenemia was compared in patients with systemic infection and in control groups; mannan was not found in patients with superficial Candida infections, colonization, or other mycotic infections, and it was detected in low titer in only $1 \%$ of 234 normal blood donors and other hospital patients. Thus, the HI assay for serum mannan permitted early, specific serologic detection of invasive Candida infection in $30 \%$ of the infected patients.

A report by Miller et al. (36), supports the concept of mannan antigenemia in Candida infections. Using gas-liquid chromatography, the authors identified abnormal chromatograms in six patients with candidemia and in two of four patients with invasive Candida infections. Co-chromatography studies suggested that the abnormal peaks could be derivitives of mannose.

A sensitive passive hemagglutination assay for antimannan antibody was also tested for its value in the diagnosis of systemic candidiasis. Antimannan antibody was found to be ubiquitous in patient and control populations. Antibody titers did not discriminate between noninvasive and systemic infection for, although titers were generally higher in patients with systemic disease, they overlapped with control groups. Also, changes in titer were not prognostic of clinical outcome or response to therapy. Rising titers could generally be detected before precipitins to "S" antigen. Similar observations have been made regarding serum agglutinins to nonviable Candida cells (13-15).

In the present study, precipitins to " $\mathrm{S}$ " antigen were detected relatively late in the course of systemic Candida infection, and were also present in 6 of 38 patients with superficial Candida infections or colonization with Candida. Other studies have demonstrated serum precipitins to somatic Candida antigens in $27-94 \%$ of patients with systemic candidiasis (37-38) and false positive precipitin reactions in $5-44 \%$ of patient controls $(5,39)$.

Because periods of dynamic interplay between mannan antigenemia and antimannan antibody were documented in cases of systemic Candida infection, we looked for soluble immune complexes and complement activation. During the transition phase from antigenemia to the appearance of mannan antibody, circulating immune complexes could not routinely be detected by the $\mathrm{C} 1 \mathrm{q}$ precipitin assay, but treatment of sera with $\alpha$-mannosidase as previously noted resulted in increased recovery of antimannan antibody, suggesting the presence of mannan-antibody complexes. Low levels of C3 and alternate complement pathway activation were detected in some patients with systemic candidiasis. Furthermore, the addition of mannan to normal serum activated $\mathrm{C} 3$ and factor $B$ in a manner similar to the activation by inulin. Also, we characterized the humoral immune response to mannan in five patients with systemic candidiasis and found that the isolated antibodies were restricted in class and subclass to $\operatorname{IgG1}, \operatorname{IgG} 2$, and $\operatorname{Ig} \mathrm{A}$. These observations suggest that in part host defense and pathogenesis of systemic Candida infection reflect the direct effects of mannan and the biologic properties of a restricted humoral response (40).

In summary, sequential studies have demonstrated episodes of mannan antigenemia followed by a rise in antimannan antibodies early in the course of disease in one-third of patients with invasive Candida infections. When patients with systemic candidiasis were compared to control groups, the detection of mannan appeared specific for the diagnosis of invasive disease. The present study, then, strongly suggests that a prospective trial of the HI assay is warranted, for mortality may be substantially reduced by early effective use of antifungal chemotherapy.

\section{ACKNOWLEDGMENTS}

The authors acknowledge Dr. H. F. Hasenclever's generous gift of $C$. albicans group A (B311) and mannans prepared from $C$. albicans group $\mathrm{B}, C$. tropicalis, and $C$. stellatoidea; and the helpful discussion and criticism of Doctors P. F. Sparling, H. M. Reisner, and E. G. Reisner. We also thank Dr. P. Imrey for his statistical assistance and Ms. B. Cherry for typing the manuscript.

\section{REFERENCES}

1. Bodey, G. P. 1966. Fungal infections complicating acute leukemia. J. Chronic Dis. 19: 667-687.

2. Eras, P., M. J. Goldstein, and P. Sherlock. 1972. Candida infection of the gastrointestinal tract. Medicine (Baltimore). $51: 367-379$. 
3. Preisler, H. D., H. F. Hasenclever, and E. S. Henderson. 1971. Anti-Candida antibodies in patients with acute leukemia. A prospective study. Am. J. Med. 51:352-361.

4. Rosner, F., F. D. Gabriel, C. L. Taschdjian, M. B. Cuesta, and P. J. Kozinn. 1971. Serologic diagnosis of systemic candidiasis in patients with acute leukemia. Am. J. Mcd. 51: 54-62.

5. Gaines, J. D., and J. S. Remington. 1973. Diagnosis of deep infection with Candida. A study of Candida precipitins. Arch. Intern. Mcd. 132: 699-702.

6. Eickhoff, T. C. 1973. Infectious complications in renal transplant recipients. Transplant. Proc. 5: 1233-1238.

7. Seelig, M. S., C. P. Speth, P. J. Kozinn, C. L. Taschdjian, E. F. Toni, and P. Goldberg. 1974. Patterns of Candida endocarditis following cardiac surgery: importance of early diagnosis and therapy (an analysis of 91 cases). Prog. Cardioz'asc. Dis. 17: 125-160.

8. Candidiasis: colonization vs. infection, editorial. 1971. JAMA (J. Am. Med. Assoc.). 215: 285-286.

9. Ellis, C. A., and M. L. Spivack. 1967. The significance of candidemia. Ann. Intern. Med. 67: 511-522.

10. Stickle, D., L. Kaufman, S. O. Blumer, and D. W. McLaughlin. 1972. Comparison of a newly developed latex agglutination test and an immunodiffusion test in the diagnosis of systemic candidiasis. Appl. Microbiol. 23: $490-499$.

11. Shannon, D. C., G. Johnson, F. S. Rosen, and K. F. Austen. 1966. Cellular reactivity to Candida albicans antigen. N. Engl. J. Med. 275: 690-693.

12. Salvin, S. B. 1959. Current concepts of diagnostic serology and skin hypersensitivity in the mycoses. $\mathrm{Am} . \mathrm{J}$. Med. 27 : 97-114.

13. Jones, S. A., M. Brennan, and R. B. Kundsin. 1973. Candida serology: an aid in diagnosis of deep-organ candidiasis. J. Surg. Res. 14: 235-237.

14. Winner, H. I. 1955. A study of $C$. albicans agglutinins in human sera. J. Hy'g. 53: 509-512.

15. Drake, C. H. 1945. Natural antibodies against yeast-like fungi as measured by slide-agglutination. J. Immunol. 50: $185-189$.

16. Bishop, C. T., F. Blank, and P. E. Gardner. 1960. The cell wall polysaccharides of Candida albicans: glucan, mannan, and chitin. Can. J. Chem. 38: 869-881.

17. Summers, D. F., A. P. Grollman, and H. F. Hasenclever. 1964. Polysaccharide antigens of Candida cell wall. J. Immunol. 92: 491-499.

18. Krick, J. A., and J. S. Remington. 1975. Treatment of fungal infections. Arch. Intern. Mcd. 135: 344-346.

19. Webb, C. D., C. Papageorge, and C. T. Hall. 1971. Identification of yeasts. Center for Disease Control. Department of Health, Education and Welfare. 1-25.

20. Taschdjian, C. L., C. B. Dobkin, L. Caroline, and P. J. Kozinn. 1964. Immune studies relating to candidiasis. II. Experimental and preliminary clinical studies on antibody formation in systemic candidiasis. Sabouraudia. 3: 129-139.

21. Lowry, O. H., N. J. Rosebrough, A. L. Farr, and R. J. Randall. 1951. Protein measurement with the Folin phenol reagent. J. Biol. Chem. 193: 265-275.

22. Peat, S., W. J. Whelan, and T. E. Edwards. 1961. Polysaccharides of baker's yeast. Part IV. Mannan. J. Chem. Soc. (Lond.). 1: 29-34.

23. Stabb, A. M. 1965. Removal of proteins. In Methods in Carbohydrate Chemistry. R. L. Whistler, editor. Academic Press Inc., New York. 5: 5-6.

24. Kabat, E. A., and M. M. Mayer. 1961. Experimental Immunochemistry. Charles C. Thomas, Publisher, Springfield, Ill. 2nd edition. 22-90.

25. Kabat, E. A., and M. M. Mayer. 1961. Experimental Immunochemistry. Charles C. Thomas, Publisher, Springfield, Ill. 2nd edition. 658-674.

26. Yu-Teh Li, and Su-Chen Li. 1972. $\alpha$-Mannosidase, $\beta$-nacetylhexosaminidase and $\beta$-galastosidase from jack bean meal. Mcthods Enzymol. 28: 703-713.

27. Agnello, V., R. J. Winchester, and H. G. Kunkel. 1970 Precipitin reactions of the $\mathrm{Clq}$ component of complement with aggregated $\gamma$-globulin and immune complexes in gel diffusion. Immnunology. 19: 909-919.

28. Mancini, G., A. O. Carbonara, and J. F. Heremans. 1965. Immunochemical quantitation of antigens by single radial immunodiffusion. Intmunochcmistry. 2: 235-254.

29. Scheidegger, J. J. 1955. Une micro-méthode de l'immunoélectrophorèse. Int. Arch. Allergy Appl. Immunol. $7: 103-110$.

30. Ouchterlony, Ö. 1953. Antigen-antibody reactions in gels. IV. Types of reactions in coordinated systems of diffusion. Acta. Pathol. Microbiol. Scand. 32: 231-240.

31. Leon, M. A., and N. M. Young. 1970. Concanavalin A : a reagent for the sensitization of erythrocytes with glycoproteins and polysaccharides. J. Immunol. 104: 15561557.

32. Coonrod, J. D., and M. W. Rytel. 1973. Detection of type-specific pneumococcal antigens by counterimmunoelectrophoresis. I. Methodology and immunologic properties of pneumococcal antigens. J. Lab. Clin. Med. 81: 770-777.

33. Edwards, E. A. 1971. Immunologic investigations of meningococcal disease. I. Group-specific Ncisseria meningitis antigens present in the serum of patients with fulminant meningococcemia. J. Immunol. 106: 314-317.

34. Goodman, J. S., L. Kaufman, and M. G. Koenig. 1971. Diagnosis of cryptococcal meningitis. Value of immunologic detection of cryptococcal antigen. N. Engl. J. Med. 285 : 434-436.

35. Hasenclever, H. F., and W. O. Mitchell. 1964. A study of yeast surface antigens by agglutination inhibition. Sabouraudia. 3 : 288-300.

36. Miller, G. G., M. W. Witwer, A. I. Braude, and C. E. Davis. 1974. Rapid identification of Candida albicans septicemia in man by gas-liquid chromatography. J. Clin. Invest. 54 : 1235-1240.

37. Kozinn, P. J., R. S. Galen, C. L. Taschdjian, P. L. Goldberg, W. Protzman, and M. A. Kozinn. 1976. The precipitin test in systemic candidiasis. JAMA (J. Am. Med. Assoc.). 235: 628-629.

38. Faux, J. A., V. C. Stanley, H. R. Buckley, and B. M. Partridge. 1975. A comparison of different extracts of Candida albicans in agar gel double diffusion techniques. J. Immunol. Methods. 6 : 235-247.

39. Murray, I. G., H. R. Buckley, and G. C. Turner. 1969. Serological evidence of Candida infection after openheart surgery. J. Med. Microbiol. 2: 463-469.

40. Weiner, M., W. Yount, and H. Reisner. 1976. Immunopathogenesis of systemic candidiasis (SC): characterization of purified antibodies and Factor $\mathrm{B}$ activation by cell wall mannan. Clin. Res. 28: 27A. (Abstr.) 